\title{
Narkolepsija: atvejo pristatymas ir literatūros apžvalga
}

\author{
E. Baltakyte்* \\ A. Popa* \\ E. Pajèdiené** \\ *Lietuvos sveikatos mokslu \\ universitetas, Medicinos fakultetas \\ **Lietuvos sveikatos mokslu \\ universitetas, Medicinos akademija, \\ Neurologijos klinika
}

\begin{abstract}
Santrauka. Narkolepsija yra viena iš centrinės kilmės hipersomnijų, pasižyminti simptomų tetrada: padidẻjusiu mieguistumu dieną, katapleksija, miego paralyžiumi ir hipnagoginėmis haliucinacijomis. Vidutiniškai narkolepsijos diagnozė yra nustatoma praejjus 10,5 metų nuo pirmųjų simptomų pasireiškimo, o tai atitolina tikslingo gydymo skyrimą ir dar labiau blogina pacientų gyvenimo kokybę. Šiame straipsnyje pristatomas diagnostinių ir terapinių iššūkių sukèlęs klinikinis I tipo narkolepsijos atvejis, aptariami svarbiausi narkolepsijos simptomai, diagnostikos ir gydymo ypatumai bei šiuo metu Lietuvoje prieinamos galimybės.
\end{abstract}

Raktažodžiai: narkolepsija, katapleksija, mieguistumas, diferencinė diagnostika.

\section{IVADAS}

Narkolepsija - tai viena iš centrinės kilmès hipersomniju, kurios pagrindiniai simptomai yra priepuolinis mieguistumas dieną, katapleksija, miego paralyžius bei hipnagoginės ir hipnopompinès haliucinacijos [1]. Tik 9,1\% pacientų ligos pradžioje yra nustatomi visi keturi simptomai [2], o 46,1-98\% pacientų ši liga pasireiškia tik padidẻjusiu mieguistumu [3]. Tai yra reta liga, dèl kurios pasaulyje kenčia 0,03-0,16 \% žmonių [4]. Narkolepsija gali pasireikšti bet kuriame amžiuje, tačiau yra du ligos išsivystymo pikai 15 ir 35 metų amžiuje [5].

Remiantis naujausia klasifikacija, narkolepsija yra skirstoma ị du tipus. I tipo narkolepsijai yra būdingi katapleksijos priepuoliai su sumažèjusiu hipokretino (oreksino A) kiekiu smegenų skystyje ( $<110 \mathrm{pg} / \mathrm{ml})$. I tipui taip pat turi būti priskiriami atvejai, kai, nesant katapleksijos, nustatomas sumažějęs hipokretino kiekis smegenų skystyje. II tipui katapleksija nèra būdinga, o hipokretino kiekis smegenų skystyje būna normalus [6]. Čia nèra kalbama apie atvejus, kai narkolepsija yra antrinè, t. y. sukelta kitų ligų ar būklių.

\footnotetext{
Adresas:

Evelina Pajédiené

Lietuvos sveikatos mokslu universitetas,

Medicinos akademija, Neurologijos klinika

Eiveniu g. 2, LT-50009 Kaunas

El.paštas evelinapajediene@gmail.com
}

Nors priimta, kad tai - nepagydoma liga, kuriai nėra būdingi remisijos epizodai, o simptomai išlieka visą gyvenimą, tačiau yra aprašyta spontaninio pasveikimo po nutraukto medikamentinio gydymo atvejų [7].

Patogenezinis I tipo narkolepsijos pagrindas yra selektyvi hipokretiną produkuojančių neuronų destrukcija pagumburyje. Hipokretinas yra peptidas, kuris, sąveikaudamas su histaminergine, noradrenergine, seratoninergine ir cholinergine sistemomis, dalyvauja palaikant normaly miego ir būdravimo ciklą [8]. Sergant narkolepsija, mieguistumo ir katapleksijos požymiai išryškẻja netekus daugiau nei 85-90\% hipokretino neuronų [9].

Ligos etiopatogenezejje yra svarbi genetinių ir aplinkos veiksnių sąveika. 87-98 \% sergančiųų I tipo narkolepsija yra HLA-DQB1*06:02 alelio nešiotojai [10]. Manoma, kad patogenezèje svarbią grandị taip pat užima imuniniai mechanizmai [11]. Keliose šalyse yra nustatytas ryšys tarp padidejjusio I tipo narkolepsijos atvejų skaičiaus ir specifinès vakcinacijos nuo H1N1 A gripo virusinès infekcijos. Taip pat galvojama, kad sezoninès infekcijos, tokios kaip gripo virusinè ar streptokokinè infekcija, yra trigeriai, dalyvaujantys ligos patogenezejje $[10,11]$. Remiantis $2018 \mathrm{~m}$. pristatyta studija, 19 pacientų, sergančių I tipo narkolepsija, kraujyje ir smegenų skystyje nustatyti CD4+ limfocitai, o keliems taip pat rasta ir CD8+ limfocitu, specifiškų hipokretino neuronams [12]. Taigi daugejja duomenų, patvirtinančių autoimuninę I tipo narkolepsijos kilmę, kai II tipo narkolepsijos patogenezè iki galo nèra aiški [13].

(C) Neurologijos seminarai, 2019. Open Access. This article is distributed under the terms of the Creative Commons Attribution 4.0 International License CC-BY 4.0 (http://creativecommons.org/licenses/by/4.0/), which permits unrestricted use, distribution, and reproduction in any medium, provided you give appropriate credit to the original author(s) and the source, provide a link to the Creative Commons license, and indicate if changes were made. 


\section{ATVEJO APRAŠYMAS}

39 metų moteris tirta LSMU KK Neurologijos klinikoje dèl pasikartojančiu mieguistumo priepuolių, kuriems negali pasipriešinti, nuovargio ir sutrikusio miego naktị. Paciente dirba pamaininị operatorès darbą gaisrinès dispečerinėje.

Paskutinius 6 metus pacientę vargina padidèjusio mieguistumo dieną epizodai, nuovargis ir nuolatinis jègų trūkumas. Užmigimai dažniausiai pasireiškia darbe sẻdint prie kompiuterio, jų metu aplinkiniai pacientès negali prižadinti. Aplinkiniams atrodo, kad ji tiesiog sėdi užsisvajojusi - nereaguoja ị aplinką, tačiau pati pacientè šiuos epizodus apibūdina kaip sustingimo jausmą, kadangi jų metu negali pajudèti.

Apie 2 metus kartojasi epizodai, kai, išliekant nesutrikusiai sąmonei, apima jausmas, kad ,atima“ rankas ir kojas, jos nutirpsta, girdi, kas vyksta aplinkui, bando tarti žodị, tačiau nepavyksta, negali pajudèti, vèliau atsiranda mieguistumas, kuriam negali pasipriešinti. Šie epizodai padažnèja nuo streso ir įtampos darbe.

Naktimis miega jautriai, tarsi būdrautų, o ịmigus vargina knarkimas. Apie 1 metus vargina košmarai, realūs kaip tikrame gyvenime, su mirties baime.

Ligos eigoje paciente tirta dèl epilepsijos (atlikta galvos smegenų magnetinio rezonanso tomografija (MRT) be pakitimų, būdravimo elektroencefalografija (EEG) - be pakitimų, miego EEG - aiškių epilepsiforminių pakitimų neregistruota), kardiogeninès kilmės sinkopès, ortostatinès hipotenzijos (Holterio monitoravimas - sinusinè tachikardija, ortostazès mėginys - polinkis ị ortostatinę hipotenziją), simptomines hipoglikemijos ir hiperkorticizmo (patologijos nenustatytos), obstrukcinès miego apnejos (OMA). İvertintas pacientès kūno masès indeksas - 24. Epworth mieguistumo skalès ịvertis - 16 balų. Paciente užregistruota polisomnografijos tyrimui $2018 \mathrm{~m}$.

Pacientè buvo tirta ir gydyta Psichiatrijos klinikoje, kur diagnozuotas generalizuoto nerimo sutrikimas ir skirti ịvairūs antidepresantai (escitalopramas, tianeptinas, fluoksetinas, paroksetinas), tačiau juos blogai toleravo ir nesulauké pakankamo terapinio efekto.
2017 m. pacientè dèl užmigimo darbo metu neteko darbo, kartu pasireiškè epizodas, kai negalëjo kontroliuoti valingų kūno judesių, kalbèti ir suprasti, ką žmonės sako.

Po šio epizodo paciente stacionarizuota ị LSMU Kauno klinikų Neurologijos skyrių, kur atliktas polisomnografijos tyrimas (nustatyta greita užmigimo trukmè, labai sutrumpejjusi paradoksinio miego latencija, padidèjęs bendras paradoksinio miego kiekis, daug prabudimų, stebėtas negausus knarkimas, tačiau reikšmingo kvėpavimo sutrikimo miegant nenustatyta (apnejų ir hipopnejjų indeksas $2,4 /$ val.)) ir daugybinis užmigimo testas (nustatyta vidutinè užmigimo trukmè -6 minutès, 1 iš 5 epizodų prasidèjo paradoksinio miego stadija).

Atsižvelgiant ị ligonès anamnezę ir nusiskundimus padidejjusio mieguistumo priepuoliai, katapleksija, miego paralyžius, hipnagoninès ir hipnopompinès haliucinacijos ir pokyčiai daugybiniame užmigimo teste bei polisomnografijoje, nustatyta I tipo narkolepsijos diagnozè.

Pacientei paaiškintas miego ir būdravimo, trumpų pogulių, mitybos režimas. Skirtas gydymas metilfenidatu $5 \mathrm{mg} /$ dieną, iš pradžių dozè buvo padidinta iki $10 \mathrm{mg} / \mathrm{die}-$ ną, o vèliau - iki $15 \mathrm{mg} /$ dieną.

Po 1 mėnesio gydymo pacientei sumažèjo mieguistumo epizodai, palaipsniui atsistatè normalus miego ir būdravimo ciklas ir labai pagerẻjo gyvenimo kokybè. Dèl padidèjusio nerimo, galimai susijusio su metilfenidato vartojimu, jo dozè sumažinta iki $10 \mathrm{mg} /$ dieną.

\section{APTARIMAS}

\section{Klinika}

Ryškus mieguistumas dieną yra pagrindinis ir pirmiausia atsirandantis simptomas, kuris drastiškai riboja paciento kasdienę veiklą ir produktyvumą. Miego priepuoliai gali pasireikšti îvairiomis aplinkybėmis, ne tik monotoniškos, bet ir aktyvios veiklos metu (valgant, einant, kalbantis) [4]. Pacientai taip pat gali patirti automatizmus - tai yra pusiau sąmoningai atliekami tam tikri veiksmai [14]. Šie mikro-

1 lentelè. Mieguistumo diferencinė diagnostika [15]

\begin{tabular}{|l|l||}
\hline Su mieguistumu susiję požymiai & Diagnozė \\
\hline $\begin{array}{l}\text { Katapleksija, hipnagoginės, hipnopompinės haliucinacijos, miego paralyžius, } \\
\text { fragmentuotas nakties miegas }\end{array}$ & Narkolepsija \\
\hline Knarkimas, buvę miego apnėjos epizodai, padidejjusios tonzilès, nutukimas & Obstrukcinė miego apnėja \\
\hline Mieguistumas sumažj̇a pailsėjus & Nepakankamo miego sindromas \\
\hline Mieguistumas ryte, didelis žvalumas naktį & Vèlyvojo miego sindromas \\
\hline $\begin{array}{l}\text { Miegas sutrikdomas dèl judesių; dažnai pasireiškia esant neramių kojų sindromui, } \\
\text { geležies trūkumui, uremijai, neuropatijai }\end{array}$ & Periodinių galūnių judesių sutrikimas \\
\hline Mieguistumas dieną atsiranda dėl naktinio darbo, nepakankamai išsimiegama dieną & Pamaininis darbas \\
\hline $\begin{array}{l}\text { Vaistai nuo nemigos, opiatai, anksiolitikai, vaistai nuo epilepsijos, antipsichoziniai } \\
\text { vaistai, antidepresantai ir kt. }\end{array}$ & Sedacinių medžiagų vartojimas \\
\hline Ištęstas nakties miegas ir ilgi poguliai, sunku prabusti iš miego & Idiopatinė hipersomnija \\
\hline $\begin{array}{l}\text { Hipotiroidizmo, Parkinsono ligos, Prader-Vilio sindromo, miotoninės distrofijos } \\
\text { ir kitų būklių bei ligų simptomai }\end{array}$ & Kita \\
\hline
\end{tabular}


miego epizodai gali tapti dažnesni pacientui bandant priešintis miego atakai [4]. Mieguistumas jaučiamas kiekvieną dieną, net esant pakankamam miegui naktic. Ir nors po pogulio sergantieji jaučiasi pailsėję, staigus mieguistumas gali sugričzti po kelių valandų [15]. Miego atakos išlieka visą gyvenimą, bet dažnai, laikui bėgant, gali palengvėti [4]. Vis dèlto priepuolinis mieguistumas - nespecifiškas narkolepsijai požymis, pasireiškiantis ir prie daugelio kitų ligų (1 lentelè).

Katapleksija yra patognominis I tipo narkolepsijos požymis. Tai yra staigus, dalinis ar visiškas skersaruožių raumenų paralyžius, sukeltas stiprių, paprastai teigiamų, emocijų [16]. Priepuoliai yra lengviau išprovokuojami nuovargio fone ir, nors retai, gali kilti savaime. $57 \%$ pacientų išsako jaučiantys artèjančią katapleksijos ataką [17]. Šių katapleksijos epizodų metu sąmonè nèra prarandama, todèl pacientas juos geba atsiminti [16]. Paveikti gali būti visi skersaruožiai raumenys, išskyrus diafragmą ir išorinius akies raumenis, o dažniausiai pasitaiko veido ar kaklo raumenų paralyžius. Paralyžius visada apima raumenis abipus. Katapleksija gali pasireikšti labai ịvairiai. Esant generalizuotai formai, asmuo staiga griūna, o dalinė dažniausiai reiškiasi dizartrija, veido trūkčiojimu, žandikaulio tremoru, galvos ar žandikaulio nusvirimu, kelių sulinkimu [16]. Patys priepuoliai yra trumpi, besitęsiantys iki kelių minučių. Pasikartojimų dažnis yra individualus - nuo 1 karto per metus iki kelių per dieną. Kartais gali pasireikšti katapleksinė būklè (angl. status cataplecticus) - tai keli iš eilès katapleksijos priepuoliai, trunkantys keletą valandų [18]. Nors išlieka visa gyvenimą, tačiau atakos, laikui bėgant, gali tapti retesnès [16].

Miego paralyžius yra nespecifinis požymis, būdingas abiem narkolepsijos tipams, o sveikoje populiacijoje nustatomas 5-40\% atvejų [1]. Jis trunka kelias sekundes ar minutes ir yra apibūdinamas, kaip negalèjimas pajudèti užmigimo ar prabudimo metu. Kartu su paralyžiumi gali pasireikšti ir hipnagoginès (panyrant ị miegą) bei hipnopompinès (prabudimo metu) haliucinacijos [19]. Nakties miegas būna fragmentuotas, su dažnais prabudimais. Būdingi paradoksinės miego fazès elgesio pokyčiai [19]. Tokios būklès, kaip obstrukcinė miego apnèja, periodinis galūnių judinimo sutrikimas, vaikščiojimas per miegus, taip pat dažniau pasitaiko sergantiesiems narkolepsija nei bendrojoje populiacijoje [15]. Miego sutrikimai paprastai su amžiumi progresuoja [18].

Maždaug pusė pacientų išsako turintys mokymosi, koncentracijos ir atminties sunkumų [20]. Šie subjektyviai jaučiami demesio koncentravimo sutrikimai labiau koreliuoja su mieguistumo sunkumu ir depresijos požymiais, nei objektyviai įvertintomis kognityvinemis funkcijomis [21].

Sergantieji narkolepsija turi daug didesnę riziką sirgti gretutinèmis ligomis, lyginant su sveikais asmenimis. Jiems dažniau kartu nustatomos kitos neurologinès, psichiatrinès ligos - depresija, generalizuoto nerimo sutrikimas, taip pat virškinamojo trakto sutrikimai, metabolinès ligos [22, 23]. Taip pat, nuo ligos pradžios šiems pacientams yra stebimas svorio didejjimas [19].

\section{Diagnostika}

Kadangi, sergant narkolepsija, vyraujantis simptomas yra ryškus mieguistumas dieną, svarbu tiksliai įvertinti šio simptomo pasireiškimą. Tam yra naudojami objektyvūs ir subjektyvūs testai.

Epworth mieguistumo skalė yra pačių pacientų atliekamas klausimynas, skirtas ịvertinti tikimybę užmigti tam tikrose skirtingose gyvenimo situacijose. Objektyviai mieguistumas yra vertinamas atliekant daugybinị užmigimo testą (angl. multiple sleep latency test, MSLT). Šis testas susideda iš 5 suplanuotų miego epizodų, trunkančių po 20 minučių, su 2 valandų pertrauka. Vertinami du parametrai - vidutinė užmigimo trukmė (angl. multiple sleep latency, MSL) ir miego struktūra - paradoksinio miego (REM) epizodų skaičius užmigimo pradžioje (angl. sleep onset REM period, SOREMP). 2 savaites prieš testą tiriamasis neturi vartoti stimuliantų, raminamujų ir REM miego fazę slopinančių vaistų (pvz., selektyviųjų serotonino-noradrenalino reabsorbcijos inhibitoriu), taip pat yra naudinga kelias savaites prieš testą pildyti miego dienoraštị ar dèvèti riešinị aktigrafijos prietaisą. Naktị prieš daugybinį užmigimo testą miego laboratorijoje atliekama polisomnografija - tai padeda ekskliuduoti kitus miego sutrikimus, pasireiškiančius mieguistumu, ir užtikrinti, kad naktị prieš testą būtų surenkamas pakankamas miego kiekis [24, 25].

Abiejų tipų narkolepsijos diagnozei būtinas mieguistumas, trunkantis 3 mėnesius ir ilgiau. I tipo narkolepsijos diagnozei būtini katapleksijos priepuoliai, sumažèjusi hipokretino koncentracija smegenų skystyje, o atliekant daugybinį užmigimo testą, užmigimo trukmė turi būti 8 minutès ir mažiau bei nustatyta 2 ir daugiau REM periodų. II tipo narkolepsija diagnozuojama esant tokiems pat daugybinio užmigimo testo rezultatams, tačiau be katapleksijos epizodų ir esant normaliam hipokretino kiekiui smegenų skystyje [6] (2 lentelè).

Nors narkolepsijos diagnozė remiasi nuodugniu anamnezès ir klinikos išaiškinimu, derinant su instrumentiniais tyrimais (polisomnografija, daugybiniu užmigimo testu), vis dèlto diagnozei patvirtinti rekomenduojama atlikti hipokretino kiekio smegenų skystyje matavimus ir nustatyti HLA-DQB1*06:02 alelius kraujyje. Mūsų šalyje kol kas galima tik nustatyti HLA-DQB1*06:02 alelius, tad diagnostiniame procese tenka kliautis klinikiniu įspūdžiu bei polisomnografijos ir daugybinio užmigimo testo rezultatais, kurie kartais skirtingų specialistų gali būti subjektyviai interpretuojami ir klaidingai teigiami dèl kitų priežasčių, tokių kaip nepakankamo miego sindromas ar sunkaus laipsnio miego apnėja. Šios narkolepsijos ir kitų centrinės kilmės hipersomnijų diagnostikos problemos buvo aptartos 2019 m. gegužès mėnesi Berne (Šveicarijoje) vykusioje konferencijoje „European Narcolepsy Master Class“ ir „Narcolepsy and Its Borderland“".

Nepaisant esamų diagnostikos metodų, vidutiniškai narkolepsijos diagnozė yra nustatoma praėjus 10,5 metų nuo pirmųų simptomų pasireiškimo [2]. Svarbiausi fak- 
2 lentelè. Narkolepsijos I ir II tipo diagnostinių kriterijų apibendrinimas [6, 19]

\begin{tabular}{|c|c|}
\hline I tipo narkolepsija & II tipo narkolepsija \\
\hline Reikalingi abu kriterijai: & Reikalingi visi kriterijai: \\
\hline $\begin{array}{l}\text { 1) Kasdieniai padidèjusio mieguistumo epizodai, } \\
\text { besitęsiantys bent } 3 \text { mėnesius }\end{array}$ & $\begin{array}{l}\text { 1) Kasdieniai padidèjusio mieguistumo epizodai, besitęsiantys bent } \\
3 \text { ménesius }\end{array}$ \\
\hline \multirow{3}{*}{$\begin{array}{l}\text { 2) Vienas ar abu toliau išvardinti teiginiai: } \\
\text { a) Katapleksija ir vidutine užmigimo trukmè }-\leq 8 \text { min } \\
\text { bei } \geq 2 \text { ankstyvi paradoksinio miego epizodai, rasti } \\
\text { MSLT ar polisomnografijos metu }\end{array}$} & 2) Katapleksijos nebuvimas \\
\hline & $\begin{array}{l}\text { 3) Vidutiné užmigimo trukmé }-\leq 8 \text { min ir } \geq 2 \text { ankstyvi paradoksinio } \\
\text { miego epizodai, rasti MSLT ar polisomnografijos metu }\end{array}$ \\
\hline & 4) Hipokretino 1 koncentracija nematuota arba ji yra $>110 \mathrm{pg} / \mathrm{ml}$ ar \\
\hline \multirow{2}{*}{$\begin{array}{l}\text { b) Sumažèjusi hipokretino } 1 \text { koncentracija }(\leq 110 \mathrm{pg} / \mathrm{ml} \\
\text { ar }<33 \% \text { nuo vidutinių kontrolinių reikšmių sveikiems } \\
\text { žmonėms) }\end{array}$} & \\
\hline & $\begin{array}{l}\text { 5) Padidèjęs mieguistumas ir (ar) daugybinio užmigimo testo } \\
\text { rezultatai nepaaiškinami kitomis priežastimis, vaistų poveikiu. }\end{array}$ \\
\hline
\end{tabular}

toriai pavèluotai diagnozei yra nespecifiniai pradiniai požymiai, ypač katapleksijos nebuvimas ligos pradžioje, per mažas bendrosios praktikos gydytojų gebėjimas atpažinti narkolepsijos simptomus (kas lemia kitos ligos diagnozavimą) ir metai, kai atsirado pirmieji požymiai (atsižvelgiant į tai, kad, laikui bėgant, didėja tiek pacientų, tiek gydytojų gebẻjimas atpažinti narkolepsijos simptomus) [2, $14,26]$. Gretutinių psichiatrinių ar kitų ligų bei narkolepsijos simptomų persidengimas dar labiau apsunkina šios būklès įtarimą ir atpažinimą [14]. Atliktoje studijoje, kurioje dalyvavo 252 pacientai, $60 \%$ ju vietoje narkolepsijos pradžioje buvo klaidingai diagnozuoti tokie sutrikimai, kaip depresija, nemiga ar obstrukcinè miego apnėja [27].

Sergančiųjų narkolepsija ịprastinio galvos smegenų magnetinio rezonanso tomografijos (MRT) tyrimo vaizdas būna normalus [28]. Daugiau informacijos gali suteikti volumetrinis tyrimas (angl. voxel-based morphometry). Remiantis juo, yra stebėtas tam tikrų galvos smegenų sričiu pilkosios medžiagos tūrio sumažejimas, tačiau duomenys išlieka dviprasmiški [29, 30].

\section{Narkolepsijos ir kitų hipersomnijų diferencinė diagnostika}

İtarus narkolepsiją, reikia pagalvoti apie daugybę kitų patologijų, ypač jei narkolepsija reiškiasi be katapleksijos. Diferencijuojant svarbu atskirti kitas hipersomnijas, kurios yra skirstomos į 8 grupes, o pagal kilmę gali būti pirminès ir antrinès [6]:

- I tipo narkolepsija

- II tipo narkolepsija

- idiopatinè hipersomnija

- Kleino-Levino sindromas

- hipersomnija dèl kitos ligos

- hipersomnija, sukelta vaistų vartojimo

- hipersomnija, atsiradusi dèl psichikos ligos

- nepakankamo miego sindromas.

3 lentelè. Centrinės kilmės hipersomnijų diferencinè diagnostika [19, 36]

\begin{tabular}{|c|c|c|c|c|}
\hline & I tipo narkolepsija & II tipo narkolepsija & $\begin{array}{l}\text { Idiopatinė } \\
\text { hipersomnija }\end{array}$ & Kleino-Levino sindromas \\
\hline Mieguistumas & \begin{tabular}{|l|} 
Kasdien kamuojantis \\
ryškus mieguistumas, \\
kuriam neimanoma pasi- \\
priešinti, pasireiškiantis \\
pastaruosius 3 mėnesius
\end{tabular} & \begin{tabular}{|l|} 
Kasdien kamuojantis \\
ryškus mieguistumas, \\
kuriam neimanoma pasi- \\
priešinti, pasireiškiantis \\
pastaruosius 3 mėnesius
\end{tabular} & $\begin{array}{l}\text { Kasdien kamuojantis } \\
\text { ryškus mieguistumas, } \\
\text { kuriam neịmanoma pasi- } \\
\text { priešinti, pasireiškiantis } \\
\text { pastaruosius } 3 \text { mėnesius }\end{array}$ & $\begin{array}{l}\text { Praeinantys mieguistumo } \\
\text { epizodai, trunkantys nuo } \\
2 \text { dienų iki } 5 \text { savaičių; jų } \\
\text { metu gali miegoti } \\
\text { 16-20 valandų per parą }\end{array}$ \\
\hline Katapleksija & Yra & Nèra & Nèra & Nèra \\
\hline Miego paralyžius* & Yra & Yra & Retai & Nèra \\
\hline $\begin{array}{l}\text { Hipnagoginės / } \\
\text { hipnopompinès } \\
\text { haliucinacijos* }\end{array}$ & Yra & Yra & Retai & Nèra \\
\hline $\begin{array}{l}\text { Fragmentuotas } \\
\text { nakties miegas }\end{array}$ & Yra & Gali būti & Nèra & Nèra \\
\hline $\begin{array}{l}\text { Daugybinis užmigimo } \\
\text { testas }\end{array}$ & \begin{tabular}{|l|} 
Vidutinė užmigimo truk- \\
mé $-<8$ min. ir 2 bei \\
daugiau REM epizodų \\
užmigimo pradžioje
\end{tabular} & \begin{tabular}{|l|} 
Vidutinė užmigimo truk- \\
mé $-<8$ min. ir 2 bei \\
daugiau REM epizodų \\
užmigimo pradžioje
\end{tabular} & \begin{tabular}{|l|} 
Vidutinè užmigimo \\
trukmè - <8 min. ir ma- \\
žiau nei 2 REM epizo- \\
dai užmigimo pradžioje
\end{tabular} & $\begin{array}{l}\text { Testą sunku atlikti epizodų } \\
\text { metu; gali būti nustatomi } \\
\text { daugybiniai REM epizodai } \\
\text { užmigimo pradžioje }\end{array}$ \\
\hline $\begin{array}{l}\text { Kiti skiriamieji } \\
\text { požymiai }\end{array}$ & $\begin{array}{l}\text { Sumažèjęs hipokretino } \\
\text { kiekis smegenų skystyje }\end{array}$ & & & $\begin{array}{l}\text { Epizodų metu: kognityvinių } \\
\text { funkcijų sutrikimas, pakitęs } \\
\text { suvokimas, valgymo sutri- } \\
\text { kimai, nepriimtinas elgesys }\end{array}$ \\
\hline
\end{tabular}

*Gali pasireikšti ir sveikiems asmenims, tačiau, sergant narkolepsija, šie požymiai yra dažnesni ir ryškesni. 
4 lentelè. Narkolepsijos sąlygotam mieguistumui ir katapleksijai gydyti skirtų vaistų apibendrinimas [19, 32]

\begin{tabular}{|c|c|c|}
\hline Vaistas & Dozavimas & Šalutiniai poveikiai \\
\hline \multicolumn{3}{|l|}{ Padidèjęs mieguistumas } \\
\hline Modafinilis (I eilès) & $100-400 \mathrm{mg} /$ parą & Galvos skausmas, nervingumas, pykinimas, burnos sausumas \\
\hline Armodafinilis (I eilès) & $100-250 \mathrm{mg} /$ parą & Galvos skausmas, pykinimas, nerimas \\
\hline Natrio oksibatas (I eilès) & $2,25-4,5 \mathrm{~g} /$ parą & $\begin{array}{l}\text { Galvos skausmas, pykinimas, svorio kritimas, depresija } \\
\text { ir nerimas. Dažniausiai priklauso nuo dozès. }\end{array}$ \\
\hline Metilfenidatas* (II eilès) & $10-60 \mathrm{mg} /$ parą & Tachikardija, hipertenzija, aritmijos, svorio kritimas \\
\hline Pitolizantas* (II eilès) & 9-36 mg/parą & Galvos skausmas, pykinimas, nemiga \\
\hline Dekstroamfetamino sulfatas (III eilės) & $5-60 \mathrm{mg} /$ parą & Aritmijos, hipertenzija, dirglumas, nemiga \\
\hline \multicolumn{3}{|l|}{ Katapleksija } \\
\hline Natrio oksibatas & $2,25-4,5 \mathrm{~g}$ & $\begin{array}{l}\text { Galvos skausmas, pykinimas, svorio kritimas, depresija ir } \\
\text { nerimas. Dažniausiai priklauso nuo dozès. }\end{array}$ \\
\hline Venlafaksinas* & $37,5-300 \mathrm{mg} /$ parą & Galvos skausmas, pykinimas, burnos sausumas, prakaitavimas \\
\hline Klomipraminas & $10-25 \mathrm{mg} /$ parą & $\begin{array}{l}\text { Ortostatinė hipotenzija, prakaitavimas, impotencija, anoreksija, } \\
\text { viduriavimas, sumažèjęs libido }\end{array}$ \\
\hline Fluoksetinas* & $20-60 \mathrm{mg} /$ parą & Nemiga, pablogèjusi seksualinė funkcija \\
\hline
\end{tabular}

*Pažymèti Lietuvoje registruoti vaistai.

\section{Gydymas}

Narkolepsijos gydymas apima tiek medikamentines, tiek nemedikamentines priemones. Čia svarbi yra miego higiena ir individuali elgesio korekcija. Pacientai turètų turèti reguliarų miego režimą, dieną planuotis miego pertraukas, vengti sotaus prisivalgymo ir, jei ịmanoma, monotoniškos veiklos bei stengtis išlikti fiziškai aktyvūs [31]. Ne mažiau svarbu, kad paciento akademinė, darbinè ir socialinè aplinka būtų informuota apie tikètinus simptomus (staigias mieguistumo ir raumenų silpnumo atakas).

Medikamentinis gydymas yra simptominis, nukreiptas i mieguistumą ir katapleksiją ir tęsiamas visą gyvenimą. Tokiam gydymui gali būti skiriami vaistų deriniai, kurių kiekvienas iš jų veikia atskirus ligos simptomus, arba vaistai, kurių poveikis apima keletą simptomų.

Pirmo pasirinkimo vaistas padidejusiam mieguistumui gydyti yra modafinilis. Tai neamfetaminu grupès būdravimą skatinantis preparatas [25]. Modafinilis yra gana gerai toleruojamas, tačiau galimi šalutiniai poveikiai: galvos skausmas, pykinimas, irzlumas, nerimas, nemiga [32]. Ypač retai gali pasireikšti Stevens-Johns sindromas [25]. Taip pat reikètų nepamiršti, kad modafinilis skatina peroralinių kontraceptikų metabolizmą [31]. Selektyvus histamino 3 receptorių antagonistas / atvirkštinis agonistas pitolizantas taip pat yra pirmos eilès vaistas, skirtas mieguistumui mažinti, kurio efektyvumas panašus ì modafinilio. Preparatas yra gerai toleruojamas, o šalutiniai poveikiai yra reti (galvos skausmas, pykinimas, nemiga). Gali būti skiriamas ir katapleksijai gydyti [33]. Antro pasirinkimo vaistai yra amfetamino dariniai (metilfenidatas). Prieš skiriant, reikia atkreipti dėmesị ị gretutines širdies, endokrinines ligas ir psichikos sutrikimus. Dèl galimo pripratimo ir priklausomybės pavojaus, amfetaminų grupès stimuliuojantys preparatai mieguistumui mažinti šiuo metu skiriami rečiau [25].
Katapleksijai gydyti plačiai vartojamas venlafaksinas - SNRI grupès antidepresantas. Skiriamos mažos dozès, efektas pasireiškia po kelių dienų [32]. Staiga nutraukus vartojimą, galimas katapleksijos paūmèjimas [31].

Natrio oksibatas yra universalus vaistas, kuris tinka mieguistumo ir katapleksijos simptomams mažinti. Jis skatina lètujuc bangų miegą ir šiek tiek veikia paradoksinio miego fazę. Taip pat teigiamai veikia ir kitus susijusius simptomus - miego paralyžių, haliucinacijas, sumažina nakties miegą trikdančių prabudimų kiekį. Terapinis efektas pasiekiamas praejjus kelioms savaitėms ar mėnesiams nuo vartojimo pradžios. Natrio oksibatas yra gerai toleruojamas, tačiau kartais gali sukelti galvos skausmą ar svaigimą, pykinimą, svorio kritimą, neramių kojų sindromą, parasomnijas, nerimą ir depresijos simptomus [25, 31].

Kol kas nèra atrastas veiksmingas patogenezinis narkolepsijos gydymas, tačiau, atsižvelgiant ị tai, kad narkolepsija galimai yra autoimuninės kilmės liga, gydant bandoma pritaikyti plazmaferezes, gliukokortikoidus ir intravenini imunoglobuliną. Manoma, kad imunoterapija galètų būti veiksminga pradejjus ją skirti, kol liga nėra įsisenejusi, tačiau šio gydymo rezultatai kol kas yra prieštaringi [34, 35].

Kiti su narkolepsija susiję simptomai, tokie kaip fragmentuotas miegas, košmariški sapnai, su miego paralyžiumi susijęs nerimas, gali būti koreguojami edukuojant pacientus, taikant miego higienos ir kognityvinès elgesio terapijos principus [19].

4 lenteleje pateikiamas visų narkolepsijos sąlygoto mieguistumo ir katapleksijai gydyti skirtu vaistu apibendrinimas [19, 32]. Lietuvoje šiuo metu registruoti tik keli vaistai mieguistumui ir katapleksijai gydyti: metilfenidato hidrochloridas (ivvairių dozių pailginto atpalaidavimo ir trumpo veikimo preparatai), pitolizantas (4,5 ir $18 \mathrm{mg}$ dozėmis), SNRI grupès antidepresantai (pvz., venlafaksinas, fluoksetinas), nors susiduriama su skyrimo ir kompensavimo problemomis. 


\section{APIBENDRINIMAS}

Nors ir reta, narkolepsija yra negalią sukelianti liga, reikalaujanti ilgalaikio gydymo, o jo laiku neskyrus, neigiamai paveikianti daugeli paciento gyvenimo sričių, ypač asmens darbingumą.

Narkolepsijos diagnostikos procesas vis dar kelia iššūkių. Tai liga, kuriai diagnozuoti bene svarbiausią reikšmę turi klinikinis vaizdas, kuris kartais neteisingai nukreipia kitų, dažnesnių, būklių link. Nors ir pasiekta pažanga, ị diagnostinius narkolepsijos kriterijus ịtraukus hipokretino kiekio matavimą smegenų skystyje, vis dèlto Lietuvoje šis tyrimas dar nèra atliekamas. Gydymo galimybes riboja tai, kad galimas tik simptominis gydymas, o mūsų šalyje iš skiriamų vaistų prieinami tik keli.

Pateiktas klinikinis atvejis yra tipinis pavyzdys, atspindintis narkolepsijos diferencinės diagnostikos keblumus ir laiku nustatytos teisingos diagnozès bei skirto gydymo svarbą.

\section{Literatūra}

1. Khan Z, Trotti LM. Central disorders of hypersomnolence: focus on the narcolepsies and idiopathic hypersomnia. Chest 2015; 148(1): 262-73. https://doi.org/10.1378/ chest.14-1304

2. Morrish E, King MA, Smith IE, et al. Factors associated with a delay in the diagnosis of narcolepsy. Sleep Med 2004; 5(1): 37-41. https://doi.org/10.1016/j.sleep.2003.06.002

3. Wu H, Zhuang J, Stone WS, et al. Symptoms and occurrences of narcolepsy: a retrospective study of 162 patients during a 10-year period in Eastern China. Sleep Medicine 2014; 15(6): 607-13. https://doi.org/10.1016/j.sleep.2013.12.012

4. Zhang J, Han F. Sleepiness in narcolepsy. Sleep Med Clin 2017; 12(3): 323-30. https://doi.org/10.1016/j.jsmc. 2017.03.008

5. Dauvilliers Y, Montplaisir J, Molinari N, et al. Age at onset of narcolepsy in two large populations of patients in France and Quebec. Neurology 2001; 57(11): 2029-33. https://doi.org/ 10.1212/WNL.57.11.2029

6. American Academy of Sleep Medicine. ICSD-3. International classification of sleep disorders: diagnostic and coding manual. $3^{\text {rd }}$ ed. Westchester, IL: American Academy of Sleep Medicine, 2014.

7. Büchele F, Baumann CR, Poryazova R, et al. Remitting narcolepsy? Longitudinal observations in a hypocretin-deficient cohort. Sleep 2018; 41(9): zsy118. https://doi.org/ 10.1093/sleep/zsy118

8. Nevárez N, de Lecea L. Recent advances in understanding the roles of hypocretin/orexin in arousal, affect, and motivation. F1000 Research 2018; 7: 1421. https://doi.org/ 10.12688/f1000research.15097.1

9. Pizza F, Vandi S, Liguori R, et al. Primary progressive narcolepsy type 1: the other side of the coin. Neurology 2014; 83(23): 2189-90. https://doi.org/10.1212/WNL. 0000000000001051

10. Bonvalet M, Ollila HM, Ambati A, et al. Autoimmunity in narcolepsy. Curr Opin Pulm Med 2017; 23(6): 522-9. https://doi.org/10.1097/MCP.0000000000000426

11. Taheri S. The immune basis of narcolepsy: what is the evidence? Sleep Med Clin 2017; 12(3): 279-87. https://doi.org/ 10.1016/j.jsmc.2017.03.004
12. Latorre D, Kallweit U, Armentani E, et al. T cells in patients with narcolepsy target self-antigens of hypocretin neurons. Nature 2018; 562: 63-8. https://doi.org/10.1038/ s41586-018-0540-1

13. Kornum BR, Knudsen S, Ollila HM, et al. Narcolepsy. Nat Rev Dis Primers 2017; 3: 16100. https://doi.org/10.1038/ nrdp. 2016.100

14. Thorpy M, Morse AM. Reducing the clinical and socioeconomic burden of narcolepsy by earlier diagnosis and effective treatment. Sleep Med Clin 2017; 12(1): 61-71. https://doi.org/10.1016/j.jsmc.2016.10.001

15. Scammell TE. Narcolepsy. N Engl J Med 2015; 373(27): 2654-62. https://doi.org/10.1056/NEJMra1500587

16. Dauvilliers Y, Siegel JM, Lopez R, et al. Cataplexy - clinical aspects, pathophysiology and management strategies. Nat Rev Neurol 2014; 10(7): 386-95. https://doi.org/10.1038/ nrneurol.2014.97

17. Overeem S, van Nues SJ, van der Zande WL, et al. The clinical features of cataplexy: a questionnaire in narcolepsy patients with and without hypocretin-1 deficiency. Sleep Med 2011; 12(1): 12-8. https://doi.org/10.1016/j.sleep. 2010.05.010

18. Dauvilliers Y, Arnulf I, Mignot E. Narcolepsy with cataplexy. Lancet 2007; 369(9560): 499-511. https://doi.org/10.1016/S0140-6736(07)60237-2

19. Dauvilliers Y, Barateau L. Narcolepsy and other central hypersomnias. Continuum (Minneap Minn) 2017; 23(4): 989-1004. https://doi.org/10.1212/CON. 0000000000000492

20. Maski K, Steinhart E, Williams D, et al. Listening to the patient voice in narcolepsy: diagnostic delay, disease burden and treatment efficacy. J Clin Sleep Med 2017; 13(3): 419-25. https://doi.org/10.5664/jcsm.6494

21. Zamarian L, Högl B, Delazer M, et al. Subjective deficits of attention, cognition and depression in patients with narcolepsy. Sleep Med 2015; 16(1): 45-51. https://doi.org/ 10.1016/j.sleep.2014.07.025

22. Black J, Reaven NL, Funk SE, et al. Medical comorbidity in narcolepsy: findings from the burden of narcolepsy disease (BOND) study. Sleep Med 2017; 33: 13-8. https://doi.org/ 10.1016/j.sleep.2016.04.004

23. Alasim H, AlQazlan S, Albanyan S, et al. Comorbid psychiatric disorders among patients with narcolepsy. Sleep Breath 2019 Jul 6. https://doi.org/10.1007/s11325-019-01890-8

24. Akintomide GS, Rickards H. Narcolepsy: a review. Neuropsychiatr Dis Treat 2011; 7: 507-18. https://doi.org/ 10.2147/NDT.S23624

25. Schneider L, Mignot E. Diagnosis and management of narcolepsy. Semin Neurol 2017; 37(4): 446-60. https://doi.org/ 10.1055/s-0037-1605554

26. Thorpy MJ, Krieger AC. Delayed diagnosis in narcolepsy: characterization and impact. Sleep Med 2014; 15(5): 502-7. https://doi.org/10.1016/j.sleep.2014.01.015

27. Carter LP, Acebo C, Kim A. Patients' journeys to a narcolepsy diagnosis: a physician survey and retrospective chart review. Postgrad Med 2014; 126(3): 216-24. https://doi.org/ 10.3810/pgm.2014.05.2769

28. Bassetti C, Aldrich MS, Quint DJ. MRI findings in narcolepsy. Sleep 1997; 20: 630-1. https://doi.org/10.1093/ sleep/20.8.630

29. Hong SB. Neuroimaging of narcolepsy and Kleine-Levin syndrome. Sleep Med Clin 2017; 12(3): 359-68. https://doi.org/10.1016/j.jsmc.2017.03.021 
30. Desseilles M, Dang-Vu T, Schabus M, et al. Neuroimaging insights into the pathophysiology of sleep disorders. Sleep 2008; 31: 777-94. https://doi.org/10.1093/sleep/31.6.777

31. Barateau L, Lopez R, Dauvilliers Y. Treatment options for narcolepsy. CNS Drugs 2016; 30(5): 369-79. https://doi.org/ 10.1007/s40263-016-0337-4

32. Kallweit U, Bassetti CL. Pharmacological management of narcolepsy with and without cataplexy. Expert Opin Pharmacother 2017; 18(8): 809-17. https://doi.org/10.1080/ 14656566.2017.1323877

33. Franceschini C, Pizza F, Antelmi E, et al. Narcolepsy treatment: pharmacological and behavioral strategies in adults and children. Sleep Breath 2019 Jul 10. https://doi.org/ 10.1007/s11325-019-01894-4

34. Ruppert E, Zagala H, Chambe J, et al. Intravenous immunoglobulin therapy administered early after narcolepsy type 1 onset in three patients evaluated by clinical and polysomnographic follow-up. Behav Neurol 2018; 2018: 1671072. https://doi.org/10.1155/2018/1671072

35. Abad VC, Guilleminault C. New developments in the management of narcolepsy. Nat Sci Sleep 2017; 9: 39-57. https://doi.org/10.2147/NSS.S103467

36. Arnulf I, Rico TJ, Mignot E. Diagnosis, disease course, and management of patients with Kleine-Levin syndrome. Lan- cet Neurol 2012; 11(10): 918-28. https://doi.org/10.1016/ S1474-4422(12)70187-4

\section{E. Baltakytė, A. Popa, E. Pajėdienė}

\section{NARCOLEPSY: A CASE REPORT AND REVIEW \\ OF LITERATURE}

\section{Summary}

Narcolepsy is one of the central hypersomnias associated with a tetrad of symptoms: excessive daytime sleepiness, cataplexy, sleep paralysis, and hypnagogic hallucinations. On average, the accurate diagnosis of narcolepsy is made after 10.5 years after the onset of the disease, therefore the treatment is delayed causing a reduced quality of life. In this paper we present a clinical case of narcolepsy type 1 causing both diagnostic and therapeutic challenges. Furthermore, the most common symptoms of narcolepsy, diagnosis, treatment options as well as possibilities to implement them in Lithuania are overviewed in this article.

Keywords: narcolepsy, cataplexy, excessive sleepiness, differential diagnosis.

Gauta:

Priimta spaudai:

20191023 20191130 